\title{
A COMPARATIVE STUDY ON ANALYSIS OF DIVIDEND DETERMINANTS OF SELECTED METAL AND CEMENT COMPANIES
}

\author{
Shivani Sharma \\ Research Scholar \\ S.D. School of Commerce \\ Gujarat University
}

\begin{abstract}
Dividends are commonly defined as the distribution of earnings (past or present) in real assets among the shareholders of the firm in proportion to their ownership. (Frankfurter and Wood) Literature regarding dividend has questioned the importance given by investors in receiving stable payments in the form of dividend vis a vis capital required by companies. This paper attempts to throw light on determinants of dividend policy and how can certain factors be considered before making a dividend decision. Metal and cement and cement products sector from Nifty 50 listed companies have been selected to know the determinants of dividend and their impact on stock prices for 10 years starting from 2009 to 2019. Regression analysis has been used to analyze the data. This study found that the earning per share is the significant determinant of dividend policy in metal industry while in cement industry the retained earnings are the significant determinant of dividend policy.
\end{abstract}

KEYWORDS: DIVIDEND, STOCKPRICE, METAL, CEMENT \& CEMENT PRODUCTS, NIFTY50, REGRESSION

\section{INTRODUCTION}

The role of capital market in shaping the economy of the country is tremendously increasing. It facilitates the behavior of saving and investment by promising returns in future. It is one of the building blocks on which the progress of the country is based.

The three decisions are crucial to all firms irrespective of size, age, nature of business, duration- investment decision, financing decision and dividend decision. These decisions determine the financial soundness and operational efficiency of the firms.

\section{IMPORTANCE OF DIVIDENDS}

There are three possible reasons for the importance of dividends. These are: the clientele effect, the need to reduce agency costs and the information signaling effect. The clientele effect refers to varying needs of different groups requiring varied dividends. Rationale for this effect include: Tax considerations, Institutional investors requirement and Individual investor preference. The particular distribution policy adopted by the business will tend to attract a particular type of investor depending on his or her cash needs and taxation position.

\section{RATIONALE FOR DIVIDEND}

The questions of "Why do corporations pay dividends?" and "Why do investors pay attention to dividends?" have puzzled both academicians and corporate managers for many years. Following are some of the reasons that corporations pay dividend-

- $\quad$ to satisfy the shareholders who have invested in the company by buying shares. These

funds are used for day to day operations, growth and expansion.

- Dividends are the means through which corporations get a chance to reward the shareholders and encourage others to buy new issues of common stock at high price.

- Dividends possess information about the earnings that are conveyed to the investors. Dividends cannot be paid unless there is sufficient cash balance and it cannot be manipulated simply by actions. Thus dividend policy is the most important signal to communicate with market participants about company's future prospects in real terms.

- Steady dividend payment assures investors that the company's reported profit is real. This increases confidence of the investors in the company. They are assured of the financial health of the companies.

- Companies that reward shareholders with dividends are showing confidence in their ability to generate growing earnings because they could afford to as lowering or making a dividend cut in the future would adversely affect their stock prices and image.

- Lenders also keep an eye on dividend payment because more dividend might lead to low cash balance thereby increasing the chances of default of payment to the lenders 


\title{
GAP iNTERDISCIPLINARITIES
} A Global Journal of Interdisciplinary Studies

\author{
( ISSN - 2581-5628) \\ Impact Factor: SJIF - 5.047, IIFS - 4.875 \\ Globally peer-reviewed and open access journal.
}

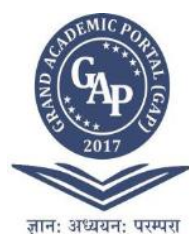

- Regular dividend paying companies attract the investors who require regular income. Non- dividend paying companies can only offer return in the form of capital appreciation. The only aim there is to watch out for stock prices to rise where $100 \%$ of your returns are compromised. Thereby dividend paying companies are preferred.

- Most of shareholders like to receive dividend and managers also create an opportunity to pay dividend when investors show interest to pay premium on dividend paying stocks and when managers are not paying dividends, investors hesitate to pay premium on non-dividend paying stocks.

Thus dividends act as barometers of financial soundness and solvency, management efficiency and overall growth of an organization.

\section{Dividend policy}

Dividend policy is the set of guidelines that company follows to decide how much portion of earnings will be distributed as dividend to shareholders. It is the plan of action that is complied with when dividend decisions are made. It allocates profit between dividend policy and retained earnings. Dividend policy should be so adjusted that there is maximum financial flexibility and avoidance of financial frictions and costs of raising external funds. Retained earnings are important for long term growth of the firm while dividend decreases the cash balance of the firm. Therefore, tradeoff is to be made between dividend payment and retained earnings.

\section{Factors Effecting Dividend Payment}

* Legal restrictions and contractual obligations

The dividend policy of the firm has to evolve within the legal framework and restrictions. For example, the Indian Companies act provides that dividend shall be declared or paid only out of the current profits or past profits after providing for depreciation. The dividend should be paid in cash, but a company is not prohibited to capitalize profits or reserves (retained earnings) for the purpose of issuing fully paid bonus shares (stock dividend). Likewise, Contractual obligation should also be fulfilled. For example, Payment of dividend on preferences shares in priority over ordinary dividends. Thus company has to consider many financial variables and constraints in deciding the amount of dividends to be distributed as dividends.

* Liquidity

Although a company may have adequate earnings to declare dividend, it may not have sufficient cash to pay dividends. Thus, the cash position of the firm is an important consideration in paying dividend. For example, a mature company is generally liquid, do not have much investment opportunity and nor much funds are tied up thereby having a sound cash position.

* Financial condition and borrowing capacity

The financial condition of firm depends on its use of borrowings and interest charges payable. A high degree of financial leverage makes a company vulnerable to changes in earnings and also becomes difficult to externally raise funds. Thus it is better to retain more. Having cash on hand affords companies flexibility to meet unforeseen operating and investing needs. Financial flexibility is important at times of crisis when liquidity dries up and credit may be hard to obtain.

* Restrictions in loan agreement

Sometimes it may such happen that lenders may put restricting clauses in their loan agreements to protect their interest and to ensure that their payment is not defaulted when firm is experiencing low liquidity or low profitability. For example, a loan agreement may prohibit payment of dividends as long as the firm's debt equity ratio is in excess of say.1.5:1.

* Access to the capital market

If a company is well established and has record of profitability, it will not be much difficult to raise funds in capital market thus providing more flexibility in paying dividends and meeting corporate obligations.

* Control

Large dividends would imply large cash outflow which would obviate the need to raise funds through issue of new shares. This would dilute the control of existing shareholders if they do not purchase new shares. Under these circumstances, more earnings may be retained to finance the investment opportunities.

* Profit stability

Businesses that have a stable pattern of profits over time are in a better position to make higher dividend pay-outs than businesses that have a volatile pattern of profits.

\section{DIVIDEND POLICY AND SHARE PRICES}

Decision of dividend is among the three major decisions of financial management. The objective should be maximizing shareholder's wealth. Tradeoff between dividend decision and retained earnings is to be made. Therefore, it is necessary to study correlation among dividend policy and share price. This is among the most puzzling situation where the empirical evidence is almost mixed. One school believes that there exists no relevance of dividend nor does it have any relation with the share price. The other believes that it is relevant and has considerable effect on the prices of shares. 


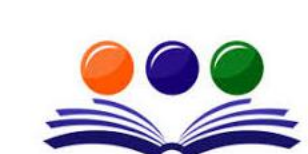

GRAND ACADEMIC PORTAL RESEARCH JOURNALS
GAP iNTERDISCIPLINARITIES A Global Journal of Interdisciplinary Studies

( ISSN - 2581-5628)

Impact Factor: SJIF - 5.047, IIFS - 4.875

Globally peer-reviewed and open access journal.

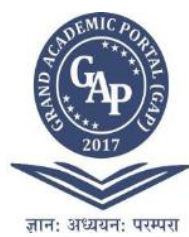

Models of both schools of thought on relationship of dividend policy \& share prices have been described as below:

\section{1) Traditional Position:}

According to the Graham Benjamin \& David L. Dodd, the stock market is more favorable on dividends than on retained earnings.

In the valuation of shares the dividend weight is four times than that of retained earnings.

The weights given by Graham \& Dodd are derived from the subjective judgments but not empirical analysis. Ignoring the subjectivity, the major conclusion is that a liberal payout policy impacts stock price in favorable way.

\section{2) Walter's Model}

Professor James E. Walter's model in 1963 puts forward the importance of dividend for maximization of wealth. He proposes that type of dividend policies most of the time affect the enterprise value. Based on certain assumptions, he shows the important relationship between firm's $\mathrm{r}$ (internal rate of return) and $\mathrm{k}$ (cost of capital) which in turn determines the dividend policy.

3) Gordon's Model

According to Gordon's dividend capitalization model, the MV of share (Pq) equals the P.V. of infinite stream of dividends that are to be received by the share.

\section{4) Modigliani and Miller Model}

states that splitting retained earnings in investments and dividends do not affect the value of firm. According to them, it is not the split of earnings that effect the share price but the potentiality of its earning and policies pursued for investment.

\section{LITERATURE REVIEW}

Dewasiri et. al. (2019) studied about determinants of dividend policy in emerging and developing market by analyzing 191 Sri Lankan firms. Past dividend decision, investment opportunity, profitability, free cash flow, corporate governance, state ownership and firm size as major determinants of propensity to pay dividends. Brahmaiah (2018) studied 95 NSE listed Firms for five years concluding that profitability, liquidity, leverage, risk, size of the firm and inflation have negative significant impact on dividend policy. Also, lagged dividend, investment opportunities, yield curve and taxation seem to not affect the dividend announcement. Azhagaiah (2014) analyzed the determinants of dividend policy by studying IT sector. Regression analysis reveals that dividend payout of IT sector is positively and significantly affected by price earnings ratio, debt equity ratio and earnings per share. The correlation analysis showed positive relationship between Debt Equity ratio and Earnings per share signaling smooth dividend pattern during the period of the study. Das \& Samanta (2013) in their study analyzed IT companies listed in Indian stock exchange for a timeline of 10 years. Regression model, Standard error and t- test were applied to test the relationship and statistical significance. They conclude that irrelevance theorem holds good even with market imperfections and the dividend policy is not at all a decisive factor for stock price behavior in information technology sector. Banerjee (2017) also studied listed top 30 companies in terms of market capitalization of Information technology in India to know about dividend determinants. Earnings per Share, Price to Earnings Ratio, Current Ratio, Life Cycle and Promoter Holding were found to be have statistically significant impact on the Dividend Payout Ratio.

Oyinlola et al. (2014) surveyed Twenty-two companies from fifteen different sub-sectors listed on Nigerian Stock Exchange (NSE) using Correlation, Regression analysis and Granger Causality Test for testing research hypothesis on 110 observations. They recommended that Nigerian firms should adopt optimal tradeoff between dividend payment and retained earnings to increase shareholders' wealth as both have a significant impact on the market value of shares. Pinto (2019) used longitudinal study for sectoral analysis of factors affecting the dividend policy. Size, profitability and interest coverage ratios had a significant positive impact on dividend policy while debt and business risk had negative relation with dividend. They also concluded that in a country like India where people prefer stable dividends, companies with lower cash flows also distribute dividends thus making unavailability of cash insignificant for dividend decision. Sectoral results observed no uniformity in dividend decision and mixed results were observed. Phan et al. (2019) examined dividend announcement and ownership pattern impact on share prices in the Vietnamese market for a period of 8 years in the paper "Dividend policy and stock price volatility in an emerging market: Does ownership structure matter?" Dividend yield has found to significantly impact the dividend policy. Also, it concluded that ownership could not contain the relation between dividend policy and stock price risk thus implying to the government that foreign holding can be invited to invest in local enterprises. 


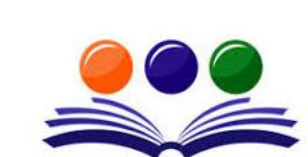

GRAND ACADEMIC PORTAL RESEARCH JOURNALS
GAP iNTERDISCIPLINARITIES A Global Journal of Interdisciplinary Studies

( ISSN - 2581-5628)

Impact Factor: SJIF - 5.047, IIFS - 4.875

Globally peer-reviewed and open access journal.

Total panel (balanced) observations: 20

\begin{tabular}{|l|l|l|l|l|}
\hline Variable & Coefficient & Std. Error & t-Statistic & Prob. \\
\hline C & 16.49095 & 10.11307 & & \\
\hline CCE & $-1.07 \mathrm{E}-05$ & 0.000193 & 1.630658 & 0.1238 \\
\hline RE & $0.000455^{*}$ & 0.000142 & -0.0551 & 0.9568 \\
\hline EPS & -0.02671 & 0.65083 & 3.207837 & 0.0059 \\
\hline PAT & -0.00074 & 0.00041 & -0.04104 & 0.9678 \\
\hline R-squared & 0.809232 & Mean dependent var & -1.79851 & 0.0922 \\
\hline Adjusted R-squared & 0.75836 & S.D. dependent var & 16.4735 & \\
\hline Prob(F-statistic) & 0.000028 & Durbin-Watson stat & 1.089605 & \\
\hline
\end{tabular}

\section{INTERPRETATION}

\section{DPR= 16.49095 -1.00007 CCE+ 0.000455 RE -0.02671EPS -0.00074 PAT}

Retained earnings seem to have significant positive impact on DPR. It implies that one unit increase in Retained earnings leads to 0.00045 unit increase in DPR keeping all other things constant. R squared is $80 \%$ meaning that $80 \%$ of variation in DPR is explained by variables namely CCE, RE, EPS and PAT. Predictive ability is strong as $\mathrm{p}$ value is 0.000028 . Hence model is strong fit. Durbin Watson is nearby 2 implying that autocorrelation is not so significant.

\section{CONCLUSION AND FINDINGS}

For the metal sector, EPS has significant negative impact on DPR while in cement sector EPS has negative insignificant impact on DPR.

PAT has significant positive impact on DPR for metal sector but it is negatively insignificant in cement sector. Profit plays a major role in declaring dividend for metal sector but doesn't have such influence in cement sector. This means that increase in profits in metal sector was followed by spillover effect in dividend payment to investors. The retained earnings have positive significant impact on metal sector whereas for cement sector it has positive insignificant impact on DPR. The Cash and Cash Equivalents has insignificant impact on DPR implying that liquid balance has not much to do with dividend announcement decision in both the industries. This may be due to the fact that Indian firms prefer to maintain stable dividend policy irrespective of cash reserve.

\section{FUTURE SCOPE}

This study adds to the existing literature and can serve as basis for further research work. It can serve as a guide for similar industries before making dividend announcement. Horizons of research design can be increased and more sample units can be added. Other studies like event studies, descriptive analysis etc. can be used to widen the scope of the study. All the sectors of Nifty 50 or other such index can be included. More number of variables can be included to deepen the insights of determinants of dividend policy and their effect.

\section{REFERENCES}

[1] Azhagaiah, R. \& Gejalakshmi, S. (2014). "Determinants of dividend policy: Evidence from IT sector in India" Pacific Business Review International, 6(11), 34-38.

[2] Banerjee, S. (2017). "Determinants of Dividend Policy of Listed Information Technology Companies in India” SCMS Journal of Indian Management, pp 54-62.

[3] Brahmaiah, B. (2018). "Determinants of Corporate Dividend Policy in India: A Dynamic Panel Data Analysis" Academy of Accounting and Financial Studies Journal, Vol. 22, Issue 2, ISSN 1528-2635-22-2-184

[4] Chawla, D. (1985). "Research Methodology concepts and cases" Vikas Publishing House Pvt. Ltd, New Delhi.

[5] Dewasiri, N., Koralalage, W.B., Azeez A. A., et al.(2019). "Determinants of dividend policy: Evidence from an emerging and developing market.” Managerial Finance, Volume 45 Issue 3, ISSN: 0307-4358 
[6] Das A. \& Samanta A. (2013). "Stock Price Behavior and Dividend Policy-An Empirical Investigation in Information Technology Sector of Corporate India in Liberalized Era” International Journal of Marketing, Financial Services \& Management Vol.2, No. 9, September 2013, ISSN 2277- 3622.

[7] Gordon, M. (1959). "Dividend, Earning, and Stock Prices”, The Review of Economics and Statistics, Vol. 41, No.2, 1959, pp. 99-105.

[8] Kothari, C.R. (1985). "Research Methodology", Vikas Publishing House Pvt. Ltd, New Delhi.

[9] Miller, H. M., \& Modigliani F. (1961). "Dividend Policy, Growth, and the Valuation of Shares" The Journal of Business, Vol. 34, No. 4. (Oct., 1961), pp. 411-433.

[10] Oyinlola, M. \& Ajeigbe, K. (2014). “The Impact of Dividend Policy On Stock Prices Of Quoted Firms In Nigeria" International Journal of Economics, Commerce and Management, United Kingdom Vol. 2, No. 9 , Sep 2014 ISSN 23480386.

[11] Pinto, G. \& Rastogi, S. (2019). "Sectoral Analysis of Factors Influencing Dividend Policy: Case of an Emerging Financial Market" Journal of Risk and Financial Management, 2019, 12(3), 110; doi:10.3390/jrfm12030110.

[12] Pandey, I.M. (2015). "Financial Management", Tenth edition, Vikas Publishing House Pvt. Ltd, New Delhi.

[13] Singh, N.P. \& Tandon A., (2019). "The Effect of Dividend Policy on Stock Price: Evidence from the Indian Market" Asia- Pacific Journal of Management Research and Innovation.

[14] Thi K. P. \& Nam H. T., (2019). "Dividend policy and stock price volatility in an emerging market: Does ownership structure matter?" Cogent Economics \& Finance, 7:1, 1637051, DOI: 10.1080/23322039.2019.1637051.

[15] Walter, E. J., (1963). “Dividend Policy: Its Influence on the Value of the Enterprise” Journal of Finance 18, pp. 280-291. 